\title{
A Systematic Review on Issues and Challenges Associated with Work Engagement of Teachers
}

\author{
Michael Ligory Santmajor 1 , Carmelita Goveas ${ }^{2}$ \& Justine P. James ${ }^{3}$ \\ ${ }^{1}$ Research Scholar, Srinivas University, Mangalore, India \\ Orcid ID: 0000-0001-8338-318X; Email: santhumayor50@gmail.com \\ ${ }^{2}$ Research Professor, Srinivas University, Mangalore, India \\ Orcid ID: 0000-0002-3240-8874; Email: dsouza.carmelita@gmail.com \\ ${ }^{3}$ Faculty, Dept of MBA, St Aloysius College (Autonomous), Mangalore, India \\ Orcid ID: 0000-0002-9660-2297; Email: justine@ staloysius.ac.in
}

Area/Section: Management.

Type of the Paper: Conceptual Research.

Type of Review: Peer Reviewed as per $|\mathrm{C}| \mathrm{O}|\mathrm{P}| \mathrm{E} \mid$ guidance.

Indexed in: OpenAIRE.

DOI: https://doi.org/10.5281/zenodo.5896729

Google Scholar Citation: $\underline{\text { IJMTS }}$

\section{How to Cite this Paper:}

Santmajor, Michael Ligory, Carmelita Goveas, \& James, Justine P., (2022). A Systematic Review on Issues and Challenges Associated with Work Engagement of Teachers. International Journal of Management, Technology, and Social Sciences (IJMTS), 7(1), 37-58. DOI: https://doi.org/10.5281/zenodo.5896729

International Journal of Management, Technology, and Social Sciences (IJMTS)

A Refereed International Journal of Srinivas University, India.

CrossRef DOI: https://doi.org/10.47992/IJMTS.2581.6012.0176

(C) With Author.

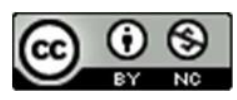

This work is licensed under a Creative Commons Attribution-Non-Commercial 4.0 International License subject to proper citation to the publication source of the work.

Disclaimer: The scholarly papers as reviewed and published by the Srinivas Publications (S.P.), India are the views and opinions of their respective authors and are not the views or opinions of the SP. The SP disclaims of any harm or loss caused due to the published content to any party. 


\title{
A Systematic Review on Issues and Challenges Associated with Work Engagement of Teachers
}

\author{
Michael Ligory Santmajor' ${ }^{1}$, Carmelita Goveas ${ }^{2}$ \& Justine P. James ${ }^{3}$ \\ ${ }^{1}$ Research Scholar, Srinivas University, Mangalore, India \\ Orcid ID: 0000-0001-8338-318X; Email: santhumayor50@gmail.com \\ ${ }^{2}$ Research Professor, Srinivas University, Mangalore, India \\ Orcid ID: 0000-0002-3240-8874; Email: dsouza.carmelita@ gmail.com \\ ${ }^{3}$ Faculty, Dept of MBA, St Aloysius College (Autonomous), Mangalore, India \\ Orcid ID: 0000-0002-9660-2297; Email: justine@ staloysius.ac.in
}

\begin{abstract}
Purpose: As education sector becomes more and more quality conscious, the nature of work involved in teaching profession undergoes dramatic changes. The various management concepts such as creativity, innovation, continuous improvement and change management become a common jargon for teachers in the current scenario. All these factors impose greater pressure and uncertainty on teachers. In the midst of all these challenges, there are multiple parameters to evaluate the performance of teachers. This sudden shift in the profession really resulted in teachers experiencing a stressful environment. The predicament of whether to focus more on traditional teaching methodology or student centric quality parameters exerts pressure on them. The New Education Policy (NEP 2020) will of course demand more involvement from teachers. In this juncture, this study proposes to conduct an analysis of various issues and challenges related to work engagement of teachers.

Design/Methodology/Approach: Literature review is conducted to analyse the concept of work engagement, work engagement of teachers and the factors influencing work engagement of teachers.

Findings/Result: Quality consciousness, innovation driven environment and implementation of National Education Policy, 2020 makes it important to be concerned about the work engagement of teachers. The transition towards a student centric curriculum is challenging and inevitable. In this context, work engagement of teachers should be given utmost importance.
\end{abstract}

Originality/Value: The antecedents and consequences of work engagement in the volatile, uncertain, complex and ambiguous environment is evaluated.

Paper Type: Conceptual Research.

Keywords: Innovation, Quality, Traditional and Modern Educational Practices, Work Engagement, Organisational Commitment, Job Satisfaction

\section{INTRODUCTION :}

In the past two decades, the world has witnessed revolutionary changes in almost all the sectors such as manufacturing, services, information technology, health sector and hospitality sector. The drastic changes taking place in this world is a testimony of the fact that incremental changes are not sufficient to ensure the existence of organisations. What is required at this juncture is drastic changes in the mindset and functioning of the organisations [1]. Teaching profession is not an exception to the change. In the traditional teaching scenario, teacher was given utmost importance. That means, we had a teacher centric approach in education. Teacher used to control each and every aspect of student learning and student had a passive role just to listen to teachers and just acquire the knowledge shared by the teacher. This kind of a teacher centric approach, neglected the learner and his/her interests. We need to acknowledge the fact that our education system has killed the innate abilities of several generations of learners. Researchers, psychologists, academicians and governments all over the world realised this mistake and had taken adequate measures to correct this in order to shift to learner centric education. It is a fact that this kind of a transformation occurred only after various industries really realised the need

Michael Ligory Santmajor, et al, (2022); www.srinivaspublication.com 
for a customer focused approach. Companies in the last few decades ensure that they respond to customer requirements in all possible ways. Nowadays, companies make use of the best possible technology to respond to customer requirements. Products are tailored according to customer's requirements. New products are designed only after consulting the customers. Education sector was very slow to understand the need for this kind of an approach. However as mentioned earlier, the various stakeholders of education sector were convinced of the need for learner centric approach.

A relevant question arises here is, with regard to the need for this kind of a shift. Modern psychologists are of the opinion that each and every individual is unique and are blessed with multiple innate talents and abilities. That means, each and every individual is talented in unique ways with his/her innate capabilities. A teacher centric education system has failed to understand this unique aspect and it is really a sad state of affairs that we could not ensure the all-round development of learners belonging to past generations. A universally accepted meaning of definition given by Mahatma Gandhi is, education is drawing out, the best in the child. Therefore, unfolding the hidden innate abilities of individuals is possible only if we say goodbye to teacher centric learning. Lack of avenues for unfolding the creativity of individuals in fact can be considered as a kind of cruelty towards learners. Therefore, opportunities to the learner to find out what he/she is good at and to develop accordingly in order to choose a career which is in tune with the abilities is in fact a fundamental right of the individual. The national educational policy and its recommendations are to be considered as an initiative in this regard. Therefore, we can arrive at a conclusion that a learner centric approach and an initiative to achieve human development in its full sense is the need of the hour.

The sudden transformation into a student centric approach created a VUCA environment (Volatility, Uncertainty, Complexity, Ambiguity) in the education sector. VUCA represents the various challenge a result of the continuous changes taking place in every sectors [2-3]. Just like any other change management processes, this transformation (New Educational Policy, 2020) too had several challenges and it may result in resistance among teachers. At the same time, it has benefitted students and has the potential to contribute to nation building. The new policies and programmes put pressure on teachers and they are not in a position to digest it and to respond to it. The emphasis on quality, innovation, continuous improvement and new governance mechanisms demands more from teachers in the form of more involvement. There is a necessity for innovation for companies at present since it has a significant role to create value and to make companies competent in the market [4]. Innovation focussed mindset is a necessity when we implement National Education Policy,2020(NEP 2020). Quality of services, mental appeal, worker competence, academic leadership and student orientation are considered as factors responsible for university reputation [5]. Therefore, ensuring quality is a must in order to ensure reputation. Ongoing development is a way to relate novel methods of performing work [6-7].

In connection to the new policies, there are lot of discussions in the academia and research circles related to work engagement of teachers. Some of the areas focussed by NEP 2020 is preventing dropouts, inclusive education, multi-disciplinary education, vocational education, digital education and professional education [8]. It is always desirable to understand the determinants of work engagement, the various issues and challenges related to work engagement and the impact of work engagement on teachers' performance. Engaged employee reveals himself/herself physically, rationally and emotionally during their role performances [9]. Employee engagement is all about establishing connections with co-workers and superiors[10]. That means, an engaged employee will be totally involved in work. An engaged employee will be ready to travel extra mile beyond his/her duties. The new scenario in education sector requires teachers who are actively engaged in order to ensure the allround development of students entrusted to the care of educational institutions. Work engagement of teachers will lead to student satisfaction [11]. This review paper is an effort to understand the various issues and challenges associated with work engagement of teachers.

\section{OBJECTIVES :}

(1) To study the concept of work engagement and its relevance in the current scenario.

(2) To examine the significance of teachers' work engagement.

(3) To review the current issues related to work engagement of teachers by means of systematic literature review.

(4) To find the gap between current status and decide the status of work engagement of teachers.

(5) To suggest future research directions of work engagement of teachers. 
(6) To analyse and identify the chosen research agendas.

\section{METHODOLOGY OF DATA COLLECTION :}

This is a conceptual paper. The information related to work engagement of teachers, factors influencing work engagement of teachers, antecedents and consequences of work engagement of teachers and above all various issues and challenges related to work engagement of teachers will be collected from various database such as Google scholar and Research Gate.

\section{RELATED WORK :}

The variables of organisational culture such as rationality, participation, collaboration, communication skill, professional orientation and leadership quality influence work engagement and the performance of teachers [12]. Through their study, they explored that organisational culture and transformational leadership significantly influence work engagement and teachers' performance. They found out that the leadership quality of the principal in an educational institution and teachers work engagement results in better performance of the institution. The authors have supported the hypotheses through empirical studies. The findings are as follows a) Organizational culture is positively related to work engagement, b) Transformational leadership highly influence work engagement, c) Work engagement is directly related to teacher's performance, d) Organizational culture has positive impact on teacher's performance. Hence, it is concluded that organizational culture is main indicator of work engagement and organizational culture and transformational leadership are the antecedents of work engagement and teacher's performance. This study on organizational culture, transformational leadership and work engagement of teachers is limited to teachers working in institutions run by one community. Hence it calls for further research on broader spectrum of institutions.

There was a study on work engagement and efficacy in relation to job satisfaction, burnout and turnover intention by means of empirical data among the teachers who are newly appointed because the previous researches excluded this category of teachers [13]. The authors proved that teacher's efficacy and work engagement negatively affect job burnout. Efficacy of teacher and work engagement are significantly related to job satisfaction and efficacy of teacher and work engagement are negatively related to intention to quit. These hypotheses are tested and proved with the help of empirical data. They suggest that the newly appointed teachers and school management have to comply with Bandura's self-efficacy theory where the teacher should increase efficacy of students and school management should promote teaching efficacy to facilitate better engagement. The limitation of the study is that it is restricted to one particular region and the newly appointed teachers were hesitant to respond to the survey.

A cross sectional data survey was conducted to explore the possible solutions to the declining educational standards in Nigeria [14]. They tested whether psychological ownership, hope and resilience will promote work engagement behaviour among teachers. In this study, the results show that psychological ownership in no way predicts work engagement behaviour among teachers. But hope and resilience are significantly connected to work engagement among teachers. The study suggested a remedy that the management should promote psychological ownership among teachers. The research unfolded the reason for declining of educational standard as diminishing organisational support by school managements to teachers. Psychological ownership feeling of teachers will influence organisational standard positively. The study though is a cross-sectional empirical study, it has generalised certain aspects and is limited to some mission schools in Nigeria.

A study taking into consideration a group of Dutch teachers using weekly work engagement model was conducted [15]. The aim of the study was to evaluate the intra personal relationship between job resources, work engagement, and job performance related to teachers. On the basis of these theories about the 'motivational potential of job resources', they anticipated that teachers weekly job resources are largely related to their week level of work engagement. The week level of work engagement is an indicator for week level of output. They tested the hypothesis that temporary work engagement has a delayed positive impact on next week's job resources. The results of the analysis significantly proved the hypothesis that, the week level independency, interaction between group leader and chances for development were positively related to weekly engagement and also proved that weekly engagement in a greater extent is positively related to weekly job performance in the subsequent week. The study proved that resourceful work environment increases teachers' feeling of work engagement. This teacher 
engagement results in a positive link with weekly job performance of teachers. The research, also established a causal relationship between week level of work engagement and job resources and suggested that engaged teachers are able to generate their own job resources. The findings of the study explored that a favourable work environment nurtures teachers weekly work engagement and has a direct positive impact on job performance of teachers. Hence job resource predictor should be an integral part of human resources training programme in the organisations.

A survey research among teachers who are employed in the basic education levels of schools in Turkey to manifest the views of teachers on work engagement and organisational commitment was undertaken[16].They conducted the study considering the concepts such as vigour, dedication and absorption. Through this study, researchers revealed that vigour, dedication and absorption are three sub dimensions of work engagement and normative feeling, continuity and affectivity are the three sub dimensions of organisational commitment. The findings of this research are, the level of work engagement of teachers is higher than the organisational commitment level of teachers. Role of gender results in the differed outcomes in terms of organisational commitment and work engagement, whereas marital status does not make any difference. It is proved by the study that seniority does not make a major difference in organisational commitment and work engagement. Teachers having experience of more than 20 years, the study shows that these have higher level of work engagement. Whereas teachers who have less than 5 years of experience have lesser level of work engagement. Teachers who are engaged workers for a long time have positive approach towards teaching and excellence. The above study is limited to a group of schools in Turkey hence may not be applicable in the same way in other places.

Ensuring career enhancement of teachers, improving their engagement at work and adding up to their employability is a major challenge for educational institutions [17]. Opportunities for career enhancement is considered as a very crucial factor in improving their work engagement and which can contribute towards career excellence. According to the study, these challenges remain till the end of their career, therefore age specific engagement initiatives are very much required. The authors highlight the fact that increased work engagement enhances teacher's performance. At the same time, it will have a pivotal role in influencing student performance. Therefore, educational institutions should make sincere efforts to study and to focus more on work engagement practices for teaching professionals.

Innovation is a key component of competitive advantage [18]. Innovation has a role in achieving improved organisational performance. The theory of resource based competitive advantage, highlights the role of various resources in improved organisational performance. The author presents employees as an important resource whose innovativeness contributes to performance. In educational institutions, teaching fraternity is considered as an important resource whose innovative work behaviour (IWB) has a bearing on institution's success. Therefore, innovative work behaviour is a testimony of engaged workers or teachers. So the article tries to highlight human resource as a key resource and tried to connect work engagement and innovative work behaviour. The author also makes an effort to connect job demands-resources model and work engagement. It is found that, job demand is negatively connected to work engagement. That means, those teachers who experience certain problems at work will not be engaged this in turn will have an impact on student satisfaction.

The emotional aspects are crucial in determining the work relationships in the teaching profession [19]. That is, the role of emotions in task relationships is important in achieving superior performance. The article also pinpoints the role of work engagement in unfolding the underlying relationships between individuals, organisational factors and performance. The author brings the term professional capital (defined by human capital, social capital and decisional capital) in order to explain these relationships. Technical competence cannot simply define effective teaching. Emotional understanding is the very basis for successful teaching. This statement tells us the importance of the concept of work engagement since it reveals that an engaged employee is emotionally involved in work and he or she becomes part and parcel of the organisation.

The organisational commitment of teachers depends upon the opportunities to learn and develop [20]. This article highlights organisational commitment as the net result of work engagement. The quality of work very much depends upon organisational commitment. The mindset to work and to comply with organisational values is in fact a predictor of work engagement. 
Table 1: Review of articles related to various issues and challenges related to work engagement of teachers.

\begin{tabular}{|c|c|c|c|}
\hline $\begin{array}{l}\text { Sl. } \\
\text { No }\end{array}$ & Area & Issues & Reference \\
\hline 1. & $\begin{array}{l}\text { Innovative teaching } \\
\text { methods }\end{array}$ & $\begin{array}{l}\text { An outlook towards advanced teaching } \\
\text { methods like workshop, brainstorming } \\
\text { sessions, small group teachings, and } \\
\text { project works. These techniques will } \\
\text { enhance learning and improves } \\
\text { efficiency of students. }\end{array}$ & $\begin{array}{l}\text { Leontyeva, E. (2017) } \\
\text { [21] }\end{array}$ \\
\hline 2. & Quality education & $\begin{array}{l}\text { Quality education is the need of the } \\
\text { hour. The study suggests a model for } \\
\text { the enhancement of the abilities of } \\
\text { youth through education, critical } \\
\text { thinking, world citizenship, and } \\
\text { imaginative understanding. }\end{array}$ & $\begin{array}{l}\text { Nussbaum, M. C. } \\
\text { (2006) [22] }\end{array}$ \\
\hline 3. & $\begin{array}{l}\text { Traditional vs. Modern } \\
\text { way of teaching }\end{array}$ & $\begin{array}{l}\text { The modern way of teaching needs to } \\
\text { be flexible and stimulating. Non- } \\
\text { cognitive learning techniques are not } \\
\text { considered effective as it does not } \\
\text { generate interest among learners to } \\
\text { actively participate in the learning } \\
\text { process. }\end{array}$ & $\begin{array}{l}\text { Mammadova - } \\
\text { GunayHasanova, I. } \\
(2019)[23]\end{array}$ \\
\hline 4. & $\begin{array}{l}\text { Organizational } \\
\text { commitment and student } \\
\text { performance }\end{array}$ & $\begin{array}{l}\text { There is a positive link between } \\
\text { organizational commitment and } \\
\text { performance of students. }\end{array}$ & $\begin{array}{l}\text { Thien, L. M., et al. } \\
\text { (2021) [24] }\end{array}$ \\
\hline 5. & $\begin{array}{l}\text { Work engagement and Job } \\
\text { satisfaction of Teachers in } \\
\text { Hong Kong }\end{array}$ & $\begin{array}{l}\text { Implications of work engagement as a } \\
\text { mediating variable for job satisfaction } \\
\text { among teachers. }\end{array}$ & $\begin{array}{l}\text { Chan, E. S., et al. } \\
(2020) \text { [25] }\end{array}$ \\
\hline 6. & $\begin{array}{l}\text { Association between the } \\
\text { various attributes of } \\
\text { university teachers' job and } \\
\text { teachers' well being }\end{array}$ & $\begin{array}{l}\text { The new challenges in teaching } \\
\text { profession mediated by emotional } \\
\text { exhaustion reduce teaching job } \\
\text { satisfaction, whereas mediation of } \\
\text { work engagement increases job } \\
\text { satisfaction. }\end{array}$ & $\begin{array}{l}\text { Han, J., et al. (2019) } \\
\text { [26] }\end{array}$ \\
\hline 7. & $\begin{array}{l}\text { Challenges faced by Indian } \\
\text { education system }\end{array}$ & $\begin{array}{l}\text { The role of work engagement and } \\
\text { organisational commitment will raise } \\
\text { the standard of higher educational } \\
\text { professionals. }\end{array}$ & $\begin{array}{l}\text { Ahuja, S., Gupta, S. } \\
\text { (2019) [27] }\end{array}$ \\
\hline 8. & $\begin{array}{l}\text { Issues related to Work } \\
\text { engagement }\end{array}$ & $\begin{array}{l}\text { Social context influences work } \\
\text { engagement where role of } \\
\text { management is crucial. }\end{array}$ & $\begin{array}{l}\text { Bakker, A. B., et al } \\
\text { (2011) [28] }\end{array}$ \\
\hline 9. & $\begin{array}{l}\text { Work engagement in } \\
\text { teaching sector }\end{array}$ & $\begin{array}{l}\text { Teacher`s experience promotes work } \\
\text { engagement and improves teaching } \\
\text { ability to meet the needs of diverse } \\
\text { student community. }\end{array}$ & $\begin{array}{l}\text { Mäkinen, M. (2013) } \\
\text { [29] }\end{array}$ \\
\hline 10. & $\begin{array}{l}\text { Relation between work } \\
\text { environment and work } \\
\text { engagement }\end{array}$ & 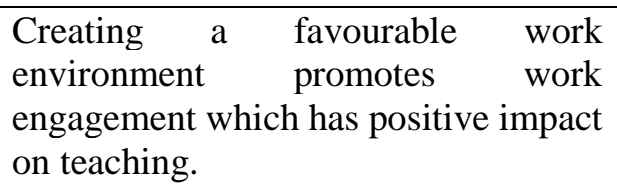 & $\begin{array}{l}\text { Federici, R. A., } \\
\text { Skaalvik, E. M. } \\
(2011)[30]\end{array}$ \\
\hline
\end{tabular}




\begin{tabular}{|c|c|c|c|}
\hline 11. & $\begin{array}{l}\text { Organisational } \\
\text { commitment }\end{array}$ & $\begin{array}{l}\text { Relationship between } \\
\text { meaningfulness, } \\
\text { engagement and } \\
\text { commitment }\end{array}$ & $\begin{array}{l}\text { Geldenhuys, M., et } \\
\text { al. (2014) [31] }\end{array}$ \\
\hline 12. & Student centric education & $\begin{array}{l}\text { Designing a student centric curriculum } \\
\text { can increase the employability of } \\
\text { teachers. }\end{array}$ & $\begin{array}{l}\text { Aithal, P. S. (2016) } \\
\text { [32] }\end{array}$ \\
\hline 13. & $\begin{array}{l}\text { Student centric education } \\
\text { in South Korea }\end{array}$ & $\begin{array}{l}\text { Switching over from exam oriented } \\
\text { system to student centric education } \\
\text { through a specific education policy }\end{array}$ & $\begin{array}{l}\text { Yang, J., \& Tan, C. } \\
\text { (2019) [33] }\end{array}$ \\
\hline 14. & $\begin{array}{l}\text { The role of self-efficacy on } \\
\text { the effects of framed health } \\
\text { messages }\end{array}$ & Effect of an individual's self-efficacy. & $\begin{array}{l}\text { Riet, J. V., et al } \\
\text { (2008) [34] }\end{array}$ \\
\hline 15. & $\begin{array}{l}\text { The influence of efficacy } \\
\text { beliefs on the performance } \\
\text { of nurses }\end{array}$ & $\begin{array}{l}\text { They establish direct connection } \\
\text { between self-efficacy and passion in } \\
\text { the context of working in which } \\
\text { efficacy beliefs reciprocally influence } \\
\text { work engagement. }\end{array}$ & $\begin{array}{l}\text { Le Blanc, P. M., } \\
\text { (2010) [35] }\end{array}$ \\
\hline 16. & $\begin{array}{l}\text { Perceptions of efficacy and } \\
\text { engagement }\end{array}$ & $\begin{array}{l}\text { High efficacy beliefs positively related } \\
\text { to intrinsic motivation at work, work } \\
\text { enjoyment, and feeling engrossed in } \\
\text { one's work. }\end{array}$ & $\begin{array}{l}\text { Salanova, M., et al. } \\
\text { (2006) [36] }\end{array}$ \\
\hline 17. & $\begin{array}{l}\text { Quality Assurance in } \\
\text { Higher education in Asia }\end{array}$ & $\begin{array}{l}\text { In order to attain quality higher } \\
\text { education, system has to restructure its } \\
\text { process, curriculum, standard and } \\
\text { monitoring system. }\end{array}$ & $\begin{array}{l}\text { Shah, M., \& } \\
\text { Do, Q. T. (2017) [37] }\end{array}$ \\
\hline 18. & $\begin{array}{l}\text { Work-life balance as a } \\
\text { determinant of job } \\
\text { engagement }\end{array}$ & $\begin{array}{l}\text { Life satisfaction mediates the } \\
\text { relationship between work-life balance } \\
\text { and work engagement. }\end{array}$ & $\begin{array}{l}\text { Žnidaršič, J., et al } \\
\text { (2020) [38] }\end{array}$ \\
\hline 19. & $\begin{array}{l}\text { Employee engagement and } \\
\text { employee performance }\end{array}$ & $\begin{array}{l}\text { Work-life balance could be described } \\
\text { as a satisfactory integration or } \\
\text { adjustment between different roles in } \\
\text { one's own life. }\end{array}$ & $\begin{array}{l}\text { Bedarkar, M., \& } \\
\text { Pandita, D. (2014) } \\
\text { [39] }\end{array}$ \\
\hline 20. & $\begin{array}{l}\text { Person-organization fit and } \\
\text { the corporate brand } \\
\text { perception of employees } \\
\text { and of customers }\end{array}$ & $\begin{array}{l}\text { Person-organization fit is the } \\
\text { consistency between individuals' } \\
\text { values and the value of the } \\
\text { organization in which they are } \\
\text { employed. }\end{array}$ & $\begin{array}{l}\text { Yaniv, E., \& } \\
\text { Farkas, F. (2005) } \\
\text { [40] }\end{array}$ \\
\hline 21. & $\begin{array}{l}\text { Work-family balance and } \\
\text { quality of life }\end{array}$ & $\begin{array}{l}\text { Balance between work and family is } \\
\text { "the extent to which an individual is } \\
\text { equally engaged in - and equally } \\
\text { satisfied with - his or her work role and } \\
\text { family role. }\end{array}$ & $\begin{array}{l}\text { Greenhaus, J. H., et } \\
\text { al. (2003) [41] }\end{array}$ \\
\hline 22. & Teacher efficacy & $\begin{array}{l}\text { Teacher efficacy as belief or } \\
\text { perceptions about his or her } \\
\text { potentialities to teach students with } \\
\text { variety of needs and to bring forth } \\
\text { desired changes in students' } \\
\text { achievement. }\end{array}$ & $\begin{array}{l}\text { Tschannen- } \\
\text { Moran, M., et al. } \\
\text { (1998) [42] }\end{array}$ \\
\hline
\end{tabular}




\begin{tabular}{|c|c|c|c|}
\hline 23. & $\begin{array}{l}\text { Individual- and } \\
\text { organizational-level } \\
\text { consequences of } \\
\text { organizational citizenship } \\
\text { behaviours }\end{array}$ & $\begin{array}{l}\text { Organisational citizenship behaviour } \\
\text { of teachers would influence } \\
\text { organisational effectiveness in } \\
\text { improving the standard and balancing } \\
\text { the activities of the institution in and } \\
\text { out, increasing the productivity and } \\
\text { enhancing stability. }\end{array}$ & $\begin{array}{l}\text { Podsakoff, N., et al } \\
\text { (2008) [43] }\end{array}$ \\
\hline 24. & Organisation support & $\begin{array}{l}\text { Organisation should realise the need of } \\
\text { appreciating and supporting } \\
\text { employees }\end{array}$ & $\begin{array}{l}\text { Hellriegel, D., et al. } \\
\text { (2012) [44] }\end{array}$ \\
\hline 25 . & $\begin{array}{l}\text { Reciprocation of perceived } \\
\text { organizational support. }\end{array}$ & $\begin{array}{l}\text { There is a link between employees } \\
\text { expectation and employees attachment } \\
\text { to the organisation. }\end{array}$ & $\begin{array}{l}\text { Eisenberger, R., et al. } \\
\text { (2001) [45] }\end{array}$ \\
\hline 26. & $\begin{array}{l}\text { Early predictors of job } \\
\text { burnout and engagement }\end{array}$ & $\begin{array}{l}\text { Burnout is a syndrome characterized } \\
\text { by emotional exhaustion, } \\
\text { depersonalization, and lack of personal } \\
\text { accomplishment. }\end{array}$ & $\begin{array}{l}\text { Maslach, C., \& } \\
\text { Leiter, M. P. (2008) } \\
\text { [46] }\end{array}$ \\
\hline 27. & $\begin{array}{l}\text { Organizational citizenship } \\
\text { behaviour }\end{array}$ & $\begin{array}{l}\text { Organizational citizenship behaviour } \\
\text { ensures that people become loyal to the } \\
\text { organization taking up various tasks } \\
\text { whole heartedly and will become } \\
\text { innovative. }\end{array}$ & $\begin{array}{l}\text { Smith, C. A., et al. } \\
\text { (1983) [47] }\end{array}$ \\
\hline 28. & $\begin{array}{l}\text { Factors influencing work } \\
\text { engagement and the effect } \\
\text { of work engagement: A } \\
\text { study in information } \\
\text { technology (IT) sector. }\end{array}$ & $\begin{array}{l}\text { Employee engagement is one of the } \\
\text { most important issues in human } \\
\text { resource management today, partly } \\
\text { because it is strongly linked to the } \\
\text { productivity of the organization. }\end{array}$ & $\begin{array}{l}\text { Sharma, U., \& } \\
\text { Rajput, B. (2017) } \\
\text { [48] }\end{array}$ \\
\hline 29. & $\begin{array}{l}\text { Importance of Job } \\
\text { engagement and the } \\
\text { measures to improve it }\end{array}$ & $\begin{array}{l}\text { Employees experiencing work } \\
\text { engagement are assets to the } \\
\text { organization. They tend to perform } \\
\text { better than people who are not engaged } \\
\text { in their work, and are less likely to } \\
\text { leave their place of employment. }\end{array}$ & $\begin{array}{l}\text { Roberts, D. R., \& } \\
\text { Davenport, T. O. } \\
\text { (2002) [49] }\end{array}$ \\
\hline 30. & $\begin{array}{l}\text { Self-efficacy and its impact } \\
\text { on online learning. }\end{array}$ & $\begin{array}{l}\text { The learner's belief on his or her } \\
\text { abilities to achieve a favourable } \\
\text { outcome has a pivotal role in the } \\
\text { teaching learning process. }\end{array}$ & $\begin{array}{l}\text { Wilde, N., Hsu, A. } \\
\text { (2019) [50] }\end{array}$ \\
\hline 31. & $\begin{array}{l}\text { Self-efficacy as a very } \\
\text { important behavioural } \\
\text { variable }\end{array}$ & $\begin{array}{l}\text { Self-Efficacy as an individual's belief } \\
\text { that they are able to succeed in any } \\
\text { given circumstance. }\end{array}$ & $\begin{array}{l}\text { Bandura, A. (1977) } \\
\text { [51] }\end{array}$ \\
\hline 32. & $\begin{array}{l}\text { The determinants of Self- } \\
\text { efficacy }\end{array}$ & $\begin{array}{l}\text { Levels of self-efficacy are not static } \\
\text { and has the ability to be increased } \\
\text { through exposure to prominent } \\
\text { information sources, one of which is } \\
\text { vicarious experience information } \\
\text { (VEI) }\end{array}$ & $\begin{array}{l}\text { Gist, M. E., } \\
\text { Mitchell, T. R. } \\
\text { (1992) [52] }\end{array}$ \\
\hline 33. & $\begin{array}{l}\text { The effect of coping and } \\
\text { buoyancy on teachers' } \\
\text { work-related well-being } \\
\text { and engagement }\end{array}$ & $\begin{array}{l}\text { Work engagement has become a } \\
\text { popular area of study in numerous } \\
\text { fields and business industries, } \\
\text { including education. }\end{array}$ & $\begin{array}{l}\text { Parker, P. D., } \\
\text { Martin, A. J. (2009) } \\
\text { [53] }\end{array}$ \\
\hline
\end{tabular}




\begin{tabular}{|c|c|c|c|}
\hline 34. & $\begin{array}{l}\text { The effect of job demands - } \\
\text { resources model on burnout } \\
\text { and engagement }\end{array}$ & $\begin{array}{l}\text { Work engagement is a positive and } \\
\text { persistent state of mind which is } \\
\text { opposite of burnout. }\end{array}$ & $\begin{array}{l}\text { Schaufeli, W. B., } \\
\text { Bakker, A. B. (2004) } \\
\text { [54] }\end{array}$ \\
\hline 35. & $\begin{array}{l}\text { The relationship between } \\
\text { engagement and burnout }\end{array}$ & $\begin{array}{l}\text { Work engagement is a positive, } \\
\text { fulfilling, work-related state of mind } \\
\text { that is characterized by vigour, } \\
\text { dedication, and absorption. }\end{array}$ & $\begin{array}{l}\text { Schaufeli, W., et al. } \\
\text { (2002) [55] }\end{array}$ \\
\hline 36. & $\begin{array}{l}\text { The role of perceived } \\
\text { organizational support in } \\
\text { achieving work } \\
\text { engagement }\end{array}$ & $\begin{array}{l}\text { Employees develop global beliefs } \\
\text { concerning the extent to which the } \\
\text { organisation values their contributions } \\
\text { and cares about their well-being. }\end{array}$ & $\begin{array}{l}\text { Eisenberger, R., et al. } \\
\text { (1986) [56] }\end{array}$ \\
\hline 37. & $\begin{array}{l}\text { The role of perceived } \\
\text { organizational support in } \\
\text { moulding affective } \\
\text { commitment }\end{array}$ & $\begin{array}{l}\text { Employees personify the organisation, } \\
\text { they view favourable or unfavourable } \\
\text { treatment as an indicator of the } \\
\text { organisation's benevolent or } \\
\text { malevolent orientation toward them" }\end{array}$ & $\begin{array}{l}\text { Rhoades, L., et al. } \\
\text { (2001) [57] }\end{array}$ \\
\hline 38. & $\begin{array}{l}\text { Workaholic and work } \\
\text { engaged employees }\end{array}$ & $\begin{array}{l}\text { Work Engagement includes a personal } \\
\text { interest in one's work as well as } \\
\text { satisfaction and sense of fulfilment } \\
\text { from the work itself. }\end{array}$ & $\begin{array}{l}\text { Van Beek, I., et al. } \\
\text { (2011) [58] }\end{array}$ \\
\hline 39. & Burnout and performance & $\begin{array}{l}\text { Job burnout increase with increase in } \\
\text { age of employees. }\end{array}$ & Gorji, M. (2011) [59] \\
\hline 40. & $\begin{array}{l}\text { Perception of standards of } \\
\text { performance and its } \\
\text { influence on complex } \\
\text { decision making. }\end{array}$ & $\begin{array}{l}\text { Higher amount of self-efficacy is } \\
\text { connected to increased motivational } \\
\text { goals, resulting in considerable effort } \\
\text { in the midst of challenges. }\end{array}$ & $\begin{array}{l}\text { Bandura, A., Wood, } \\
\text { R. (1989) [60] }\end{array}$ \\
\hline 41. & $\begin{array}{l}\text { Openness of engaged } \\
\text { employees }\end{array}$ & $\begin{array}{l}\text { Engaged employees have an open } \\
\text { mindset with willingness to perform } \\
\text { extra roles and the ability to adjust } \\
\text { various factors of work engagement in } \\
\text { order to remain engaged. }\end{array}$ & $\begin{array}{l}\text { Bakker A. B. (2014) } \\
\text { [61] }\end{array}$ \\
\hline 42. & Student engagement & $\begin{array}{l}\text { Student centric education system } \\
\text { promotes higher level of student } \\
\text { engagement in learning process. }\end{array}$ & $\begin{array}{l}\text { Shailashri V. T. } \\
\text { (2016) [62] }\end{array}$ \\
\hline 43. & Teacher Quality & $\begin{array}{l}\text { Teacher quality influences teaching - } \\
\text { learning process and improves } \\
\text { learning outcomes. As a result it } \\
\text { promotes institutional excellence. }\end{array}$ & $\begin{array}{l}\text { Aithal P. S., Kumar } \\
\text { S. P. M. (2016) [63] }\end{array}$ \\
\hline 44. & Quality of Education & $\begin{array}{l}\text { The role of various methods of student } \\
\text { assessment in ensuring quality } \\
\text { education. }\end{array}$ & Wagner (2010) [64] \\
\hline 45. & $\begin{array}{l}\text { Quality and quantity of } \\
\text { education }\end{array}$ & $\begin{array}{l}\text { GDP growth is increased because of } \\
\text { quality of education and quantity of } \\
\text { education }\end{array}$ & $\begin{array}{l}\text { Deme et } \\
\text { al.(2020)[65) }\end{array}$ \\
\hline 46. & Quality of Education & $\begin{array}{l}\text { The number of children enrolling to } \\
\text { primary education is more in Kenya. } \\
\text { Now, the challenge is to improve } \\
\text { quality of education }\end{array}$ & $\begin{array}{l}\text { Miller, Elman (2013) } \\
\text { [66] }\end{array}$ \\
\hline
\end{tabular}




\begin{tabular}{|c|c|c|c|}
\hline 47. & $\begin{array}{l}\text { Quality Function } \\
\text { Deployment }\end{array}$ & $\begin{array}{l}\text { The role of quality function } \\
\text { deployment in improving global } \\
\text { competitiveness of education }\end{array}$ & $\begin{array}{l}\text { Sagnak et al. (2017) } \\
{[67\}}\end{array}$ \\
\hline 48. & $\begin{array}{l}\text { Investment in education } \\
\text { and improvement of } \\
\text { Quality }\end{array}$ & $\begin{array}{l}\text { The relationship between spending in } \\
\text { education sector by the government } \\
\text { and improvement of quality }\end{array}$ & Haddad (2016) [68] \\
\hline 49. & Quality of Teaching & $\begin{array}{l}\text { A better teaching evaluation process } \\
\text { can improve the quality of teaching. } \\
\text { Without a proper teaching evaluation } \\
\text { system, teaching quality will not be } \\
\text { improved. }\end{array}$ & Ji, Z. (2009) [69] \\
\hline 50. & $\begin{array}{l}\text { School based activities and } \\
\text { quality of education }\end{array}$ & $\begin{array}{l}\text { The view point of students on the } \\
\text { effect of school- based activities on the } \\
\text { quality of education. Teacher`s quality } \\
\text { and school management teams affect } \\
\text { the quality of education. }\end{array}$ & $\begin{array}{l}\text { Kariyana, Sonn } \\
\text { (2014) [70] }\end{array}$ \\
\hline 51. & Quality of education & $\begin{array}{l}\text { Teachers in contract terms in Canada } \\
\text { affects the quality of education. In this } \\
\text { era of globalisation of education, this } \\
\text { is a hindrance to achieve } \\
\text { competitiveness. }\end{array}$ & Hasrati (2021) [71] \\
\hline 52. & $\begin{array}{l}\text { Quality education to } \\
\text { underprivileged sectors }\end{array}$ & $\begin{array}{l}\text { Inequalities in imparting quality } \\
\text { education to the less advantaged } \\
\text { segments is a challenge in human } \\
\text { development }\end{array}$ & Santos (2009) [72] \\
\hline 53. & $\begin{array}{l}\text { Reforming schools in rural } \\
\text { areas and ensuring quality } \\
\text { education }\end{array}$ & $\begin{array}{l}\text { In order to ensure quality education, } \\
\text { schools in rural areas needs to be } \\
\text { upgraded as per the modern standards. } \\
\text { With modern facilities will help } \\
\text { children to excel in education }\end{array}$ & $\begin{array}{l}\text { Stepanova (2004) } \\
{[73]}\end{array}$ \\
\hline 54. & $\begin{array}{l}\text { Quality of education and } \\
\text { economic growth }\end{array}$ & $\begin{array}{l}\text { Population explosion and slowing } \\
\text { down of economic growth will affect } \\
\text { the quality of education }\end{array}$ & $\begin{array}{l}\text { Musambachime } \\
\text { (1990) [74] }\end{array}$ \\
\hline 55. & $\begin{array}{l}\text { Assessment in education } \\
\text { sector }\end{array}$ & $\begin{array}{l}\text { Evaluation and assessment of } \\
\text { education is the essence of ensuring } \\
\text { quality. Customisation of education is } \\
\text { also a necessary task. }\end{array}$ & $\begin{array}{l}\text { Gurovaet al. (2015) } \\
\text { [75] }\end{array}$ \\
\hline 56. & $\begin{array}{l}\text { Education for national } \\
\text { development and for the } \\
\text { growth of the society. }\end{array}$ & $\begin{array}{l}\text { The role of education is to prepare } \\
\text { students to learn continuously even } \\
\text { after formal education to contribute to } \\
\text { the development of the nation. }\end{array}$ & Zholkov (2010) [76] \\
\hline 57. & $\begin{array}{l}\text { Creativity and Innovation } \\
\text { and education }\end{array}$ & $\begin{array}{l}\text { The role of education in developing a } \\
\text { work force that has the capacity to } \\
\text { embrace creativity and innovation. I is } \\
\text { needed for the development of the } \\
\text { nation. }\end{array}$ & $\begin{array}{l}\text { Croslinget al. (2014) } \\
\text { [77] }\end{array}$ \\
\hline 58. & $\begin{array}{l}\text { Role of Information } \\
\text { Technology in education }\end{array}$ & $\begin{array}{l}\text { The various benefits of information } \\
\text { technology should be utilised to } \\
\text { improve the quality of education. } \\
\text { Information technology can enhance }\end{array}$ & Kong (2009) [78] \\
\hline
\end{tabular}




\begin{tabular}{|c|c|c|c|}
\hline & & $\begin{array}{l}\text { the effectiveness of teaching and } \\
\text { learning. }\end{array}$ & \\
\hline 59. & $\begin{array}{l}\text { Organisational confidence } \\
\text { level of teachers and } \\
\text { managers }\end{array}$ & $\begin{array}{l}\text { The organisational confidence level of } \\
\text { teachers and managers in schools } \\
\text { affect the quality of education. }\end{array}$ & $\begin{array}{l}\text { Karademir (2015) } \\
\text { [79] }\end{array}$ \\
\hline 60. & $\begin{array}{l}\text { Work engagement and job } \\
\text { burnout of physicians }\end{array}$ & $\begin{array}{l}\text { Work engagement leads to overall } \\
\text { well-being of the person and reduces } \\
\text { the chances of burnout. }\end{array}$ & $\begin{array}{l}\text { Loerbroks et al. } \\
\text { (2017) [80] }\end{array}$ \\
\hline 61. & Innovation in schools & $\begin{array}{l}\text { The extent of innovation in schools is } \\
\text { affected by the principal's work } \\
\text { engagement. }\end{array}$ & Koch et al.(2014)[81] \\
\hline 62. & $\begin{array}{l}\text { Job resources, self efficacy, } \\
\text { work engagement. }\end{array}$ & $\begin{array}{l}\text { Work engagement is considered as a } \\
\text { process which is developed over time. } \\
\text { This kind of an approach provides } \\
\text { insights on the activities to be } \\
\text { undertaken to develop work } \\
\text { engagement over time }\end{array}$ & $\begin{array}{l}\text { Simbula et al. (2011) } \\
\text { [82] }\end{array}$ \\
\hline 63. & $\begin{array}{l}\text { Work engagement, ethical } \\
\text { leadership and voice } \\
\text { behaviour. }\end{array}$ & $\begin{array}{l}\text { Ethical leadership induces followers to } \\
\text { be more engaged at work. There is a } \\
\text { positive relationship between ethical } \\
\text { leadership and work engagement. }\end{array}$ & $\begin{array}{l}\text { Cheng et al. (2014) } \\
\text { [83] }\end{array}$ \\
\hline 64. & $\begin{array}{l}\text { Work engagement of } \\
\text { teachers of various age } \\
\text { groups. }\end{array}$ & $\begin{array}{l}\text { The extent of work engagement } \\
\text { changes in different age groups. } \\
\text { Young teachers value career } \\
\text { enhancement more and older ones will } \\
\text { be happy with the organisation if it } \\
\text { acknowledges their contribution. }\end{array}$ & $\begin{array}{l}\text { Guglielmi et al. } \\
\text { (2015) [84] }\end{array}$ \\
\hline 65. & $\begin{array}{l}\text { Job engagement and } \\
\text { performance }\end{array}$ & $\begin{array}{l}\text { Work engagement ultimately leads to } \\
\text { performance. That means task } \\
\text { performance and organisational } \\
\text { citizenship behaviour. Work } \\
\text { engagement is considered as the } \\
\text { investment of whole self by the } \\
\text { individual for the role performance. }\end{array}$ & $\begin{array}{l}\text { Rich et al. (2010) } \\
\text { [85]) }\end{array}$ \\
\hline 66. & $\begin{array}{l}\text { Antecedents of teachers` } \\
\text { innovative work behaviour. }\end{array}$ & $\begin{array}{l}\text { Learning organisation and work } \\
\text { engagement are identified as two } \\
\text { factors influencing work } \\
\text { engagement.AS a result of changing } \\
\text { environment, innovation is very } \\
\text { important for organisations. In } \\
\text { connection to this, innovative } \\
\text { behaviour is expected out of teachers } \\
\text { too. }\end{array}$ & $\begin{array}{l}\text { Hosseini et al. (2021) } \\
\text { [86] }\end{array}$ \\
\hline 67. & $\begin{array}{l}\text { Developmental leadership } \\
\text { and work engagement. }\end{array}$ & $\begin{array}{l}\text { Developmental leadership has a } \\
\text { positive association with work } \\
\text { engagement }\end{array}$ & $\begin{array}{l}\text { Ryu, Shim (2020) } \\
\text { [87] }\end{array}$ \\
\hline 68. & $\begin{array}{l}\text { The role of meditation in } \\
\text { developing work } \\
\text { engagement }\end{array}$ & $\begin{array}{l}\text { Work engagement is more in where } \\
\text { mindfulness meditation courses are } \\
\text { taught. The relationship between }\end{array}$ & $\begin{array}{l}\text { Petchsawang, } \\
\text { McLean (2017) [88] }\end{array}$ \\
\hline
\end{tabular}




\begin{tabular}{|c|c|c|c|}
\hline & & $\begin{array}{l}\text { meditates the relationship between } \\
\text { meditation and work engagement }\end{array}$ & \\
\hline 69. & $\begin{array}{l}\text { The determinants of work } \\
\text { engagement }\end{array}$ & $\begin{array}{l}\text { Job resources and personal resources } \\
\text { are two important determinants of } \\
\text { work engagement. }\end{array}$ & $\begin{array}{l}\text { Miner et } \\
\text { al.(2015)[89] }\end{array}$ \\
\hline 70. & Ethical leadership & $\begin{array}{l}\text { Ethical leadership motivates } \\
\text { employees to be engaged at work } \\
\text { experiencing more vigor, dedication } \\
\text { and absorption at work. }\end{array}$ & $\begin{array}{l}\text { Den Hartog, } \\
\text { Belschak (2012) [90] }\end{array}$ \\
\hline 71. & $\begin{array}{l}\text { The role of work } \\
\text { engagement in the } \\
\text { relationship between work- } \\
\text { family conflict and work } \\
\text { engagement. }\end{array}$ & $\begin{array}{l}\text { The partial mediating role of work } \\
\text { engagement in the relationship } \\
\text { between work family conflict and } \\
\text { work engagement. Work engagement } \\
\text { is highlighted as an important concept } \\
\text { in positive psychology. }\end{array}$ & $\begin{array}{l}\text { Yucel et al. (2021) } \\
{[91]}\end{array}$ \\
\hline 72. & $\begin{array}{l}\text { High commitment work } \\
\text { systems and work } \\
\text { engagement }\end{array}$ & $\begin{array}{l}\text { Work engagement is considered as a } \\
\text { prominent concept in positive } \\
\text { psychology. High commitment work } \\
\text { systems will result in work } \\
\text { engagement. }\end{array}$ & Sekhar (2021) [92] \\
\hline 73. & $\begin{array}{l}\text { Autonomy of private } \\
\text { universities and } \\
\text { opportunities for } \\
\text { excellence }\end{array}$ & $\begin{array}{l}\text { The scope for innovation is more for } \\
\text { private universities. The autonomy for } \\
\text { private universities can take it to } \\
\text { excellence. There are several } \\
\text { challenges for campus-based } \\
\text { universities such as technology } \\
\text { adoption, return on investment, } \\
\text { maintaining discipline and online } \\
\text { education support }\end{array}$ & $\begin{array}{l}\text { Aithal, P. S., \& } \\
\text { Aithal, S. (2019) [93] }\end{array}$ \\
\hline 74 . & $\begin{array}{l}\text { Analysis of new education } \\
\text { policy }\end{array}$ & $\begin{array}{l}\text { The new education policy is analysed } \\
\text { and recommendations are provided for } \\
\text { its successful implementation. The } \\
\text { need for a progressive curriculum, the } \\
\text { necessity to have research focus, } \\
\text { multidisciplinary approach, } \\
\text { collaboration with industry and } \\
\text { collaboration with other universities } \\
\text { and educational institutions are } \\
\text { highlighted by the authors. }\end{array}$ & $\begin{array}{l}\text { Aithal, P. S., \& } \\
\text { Aithal, S. (2020) [94] }\end{array}$ \\
\hline 75. & $\begin{array}{l}\text { Opportunities and } \\
\text { Challenges associated to } \\
\text { private universities }\end{array}$ & $\begin{array}{l}\text { The opportunities and challenges for } \\
\text { private universities with regard to } \\
\text { research and development, foreign } \\
\text { collaborations, evaluation process, } \\
\text { governance, leadership and } \\
\text { management are assessed. }\end{array}$ & $\begin{array}{l}\text { Aithal, Suresh Kumar } \\
\text { (2016) [95] }\end{array}$ \\
\hline 76 & $\begin{array}{l}\text { Student perception towards } \\
\text { printed study materials }\end{array}$ & $\begin{array}{l}\text { Provision of digital and physical } \\
\text { learning materials help students to } \\
\text { learn better and which results in better } \\
\text { academic performance. }\end{array}$ & $\begin{array}{l}\text { Bhatta B., Kumar S. } \\
\text { G. (2007) [96] }\end{array}$ \\
\hline
\end{tabular}




\begin{tabular}{|c|c|c|c|}
\hline 77 & $\begin{array}{l}\text { Innovations in teaching } \\
\text { profession }\end{array}$ & $\begin{array}{l}\text { In teaching profession faculty need to } \\
\text { innovative keeping abreast with } \\
\text { modern and latest developments. This } \\
\text { will motivate student community to } \\
\text { develop creativity skills and enhances } \\
\text { employability. }\end{array}$ & $\begin{array}{l}\text { Varambally, et all } \\
\text { (2020) [97] }\end{array}$ \\
\hline 78 & $\begin{array}{l}\text { Innovation and employee } \\
\text { engagement }\end{array}$ & $\begin{array}{l}\text { Freedom for creative thinking, } \\
\text { sustained motivation and } \\
\text { encouragement by the organization } \\
\text { leads to innovations. Opportunities for } \\
\text { Innovation lead employees to engage } \\
\text { better. }\end{array}$ & $\begin{array}{l}\text { Shailashree V. T., } \\
\text { Shenoy, S. (2016) } \\
\text { [98] }\end{array}$ \\
\hline 79 & Behaviour and attitude & $\begin{array}{l}\text { Disposition and attitude of a leader at a } \\
\text { given situation and time influences the } \\
\text { decision making process. A positive } \\
\text { attitude of a leader will result in better } \\
\text { output. }\end{array}$ & $\begin{array}{l}\text { Aithal, P. S., Aithal. } \\
\text { S. (2019) [99] }\end{array}$ \\
\hline 80 & $\begin{array}{l}\text { Education and global } \\
\text { relevance }\end{array}$ & $\begin{array}{l}\text { India has a hub of young talents. These } \\
\text { talents to be rightly nurtured and } \\
\text { oriented towards acquiring adequate } \\
\text { global competence to face the global } \\
\text { competition. }\end{array}$ & $\begin{array}{l}\text { Shailashree V. T., } \\
\text { Shenoy, S. (2017) } \\
{[100]}\end{array}$ \\
\hline 81 & $\begin{array}{l}\text { Quality in Higher } \\
\text { Education }\end{array}$ & $\begin{array}{l}\text { Higher education system should take } \\
\text { aspiring students to a realm of new } \\
\text { knowledge, connected to different } \\
\text { walks of life through research and } \\
\text { innovations. }\end{array}$ & $\begin{array}{l}\text { Aithal, P. S., et al. } \\
\text { (2015) [101] }\end{array}$ \\
\hline
\end{tabular}

\section{NEW RELATED ISSUES :}

The new educational policy (NEP 2020) demands more commitment and involvement from employees. In this juncture, ensuring work engagement and job satisfaction among teachers is a difficult task.

\section{IDEAL SOLUTION AND PRESENT STATUS :}

Post-independence period to the period of globalisation witnessed a very traditional way of knowledge transfer in Indian education sector. Post globalisation period (after 1990) there was an urge to incorporate modern educational practices and to benchmark our institutions with globally renowned ones. This desire has become a reality with the new education policy. At present, nothing much is done to apply various management principles in various aspects of administration in educational institutions in tune with New Education Policy.

\section{RESEARCH GAP :}

As mentioned above, the transition to a student centric approach will become possible only if our institutions have become quality conscious and only if we focus on innovation. Quality consciousness and an innovation driven environment are possible when we channelize our human resources in this regard. Hard work, commitment and involvement of teachers are a prerequisite for achieving this. Therefore, analysing the role of various managerial and behavioural variables in ensuring teachers commitment is the need of the hour. How can we ensure optimum utilisation of human resources (which in turn can be called as work engagement), what constitutes work engagement among teachers and what are the outcomes of teachers work engagement can be unfolded with the help of further research.

\section{RESEARCH AGENDAS :}

(a) Every institution can have a unique HR policy. 
(b) Employees (in this case teachers) should develop the belief that they are part of developing future leaders and they are involved in nation building.

(c) Training programs can be conducted in order to convince teachers of the need for quality consciousness and innovation driven mindset.

(d) Since new education policy is going to be implemented, teachers should be given training on the various aspects of this policy.

\section{ANALYSIS OF RESEARCH AGENDAS :}

The most important step to be undertaken is to conduct training program on new education policy, 2020. Next step can be training on quality and innovation so that educational institutions can develop a new culture. As mentioned above, giving importance to HR policies can also revive educational institutions through engaged employees.

\section{RESEARCH TOPIC :}

Dimensions of Work Engagement and Its Impact on Organizational Citizenship Behaviour: - A Study Among the College Teachers of Dakshina Kannada District.

\section{ABCD ANALYSIS OF THE CHOSEN RESEARCH PROPOSAL :}

A: The present study will add new knowledge to the literature by studying the antecedent variables and consequent variables through a mediating variable to the level of work engagement among teaching staff.

B: This will help the Department of Collegiate Education and local college managements to analyse the level of engagement of teachers employed and it will enable them in designing different human resource management policies.

C: The study deals with work engagement where the disparity in cadre of teachers from lower to higher education, aided to unaided hence it is a challenge to expect uniform level of engagement.

D: Since this study deals with engagement there is a possibility of in genuineness as far as the data collection is concerned. Also, the data collection is difficult since it is time consuming.

\section{LIMITATIONS :}

The study is limited to the colleges of Dakshina Kannada district. Therefore generalisation of findings to the institutions of other districts may not be correct. Since, the study involves Government paid and Management paid employees, there are hurdles to get genuine data from all institutions.

Prejudices and biases from respondent's side cannot be ruled out. The respondents may not express their exact viewpoints corresponding to the questions.

The changed scenario in the new normal post Covid times may influence the findings of the study because the challenges associated with Covid at an individual level, changed thinking patterns, emotions, feelings and overall change in behavioural pattern of individuals may influence their response towards the various questions.

\section{CONCLUSION :}

There is wide spread discussion on human development index all over the world. Quality education is one of the factors that lead to increased human development index. It is in this context that, this review paper on work engagement of teachers especially in this time of NEP 2020 implementation is extremely significant. Satisfaction of teachers, their willingness to go extra mile beyond their roles, their commitment and involvement towards work are going to be much researched topics in this era of NEP implementation. The uncertainty associated with the outcome of any new policy is a matter of concern among all. It is true that revamping of educational policy is a must. Assuring the satisfaction of teachers, in tune with the implementation of new policy, is of utmost concern. Further research on work engagement in this context will unfold the various aspects of teachers' commitment at work.

\section{REFERENCES :}

[1] Liu, Zhou, Liu, \& Xin. (2020). Is the uncertainty of gaining legitimacy from organizational change an antecedent of employees' resistance to change? Chinese Management Studies, 15(4), 769-784.

Google Scholar $\chi^{\top}$ 
[2] Whiteman, W. E. (1998). Training and educating army officers for the 21st century: Implications for the United States Military Academy, Army War Coll Carlisle Barracks PA, 1(1), 1-32.

Google Scholar $X^{\nearrow}$ CrossRef $x^{\top}$

[3] Saleh, A., \& Watson, R. (2017). Business excellence in a volatile, uncertain, complex and ambiguous environment (BEVUCA). The TQM Journal, 29(5), 705-724. Google Scholar $\chi^{\prime}$

CrossRef $X$

[4] Subramaniam, M., \& Youndt, M. A. (2005). The influence of intellectual capital on the types of innovative capabilities. Academy of Management Journal, 48(3), 450-463. Google Scholar $x^{7}$

CrossRef $x^{\top}$

[5] Dursun, O., \&AltinGumussoy, C. (2021). The effects of quality of services and emotional appeal on university reputation: Stakeholders' view. Quality Assurance in Education, 29 (2/3), 166-182. Google Scholar $x^{\nearrow}$

[6] Anand, G., Ward, P. T., Tatikonda, M. V., \& Schilling, D. A.(2009). Dynamic capabilities through continuous improvement infrastructure. Journal of Operations Management, 27(6), 444-461. Google Scholar X CrossRef $X^{7}$

[7]Eaidgah, Y., Maki, A. A., Kurczewski, K., \&Abdekhodaee, A. (2016). Visual management, performance management and continuous improvement. International Journal of Lean Six Sigma, 7(2), 187-210.

Google Scholar $x^{\top}$

\section{CrossRef $x^{\lambda}$}

[8] Government of India, Ministry of Human Resource Development. (2020). National Education Policy 2020. Major Initiatives, Government of India, Ministry of Education. https://www.education.gov.in/en/relevant-documents, 1-60. CrossRef $x^{\top}$

[9] Kahn, W. A. (1990). Psychological conditions of personal engagement and disengagement at work. Academy of Management Journal, 33(4), 692-724.

Google Scholar ${ }^{\top}$

CrossRef $x^{7}$

[10] Luthans, F., \& Peterson, S. J. (2002). Employee engagement and manager self-efficacy. Journal of Management Development, 21(5), 376-387.

Google Scholar $\chi^{\top} \quad \underline{\text { CrossRef }} \not 7$

[11] Bilal, A. R., Fatima, T., Bin Dost, K., \& Imran, M. K. (2021). I am engaged, therefore my students are satisfied! Unleashing the role of teachers' interaction and sensitivity based on selfdetermination perspective. International Journal of Educational Management, 35(1), 341-361.

Google Scholar ${ }^{\top}$

CrossRef

[12] Arifin, F., Troena, E. A., Djumahir, \&Rahayu, M. (2014). Organizational culture, transformational leadership, work engagement and teacher's performance: test of a model. International Journal of Education and Research, 2(1), 1-14.

Google Scholar $x^{\top}$

[13] Høigaard, R., Giske, R., \&Sundsli, K. (2011). Newly qualified teachers’ work engagement and teacher efficacy influences on job satisfaction, burnout, and the intention to quit. European Journal of Teacher Education, 35(3), 347-357.

Google Scholar $X^{\top}$

CrossRef $x$

[14] Ugwu, F. O., \&Amazue, L. O. (2014). Psychological ownership, hope, resilience and employee work engagement among teachers in selected mission schools. European Journal of Business and Management, 6(10), 98-106.

Google Scholar $x^{7}$

[15] Bakker, A. B., \& Bal, M. P. (2010). Weekly work engagement and performance: A study among starting teachers. Journal of Occupational and Organizational Psychology, 83(1), 189-206.

Google Scholar $\chi^{\top} \quad \underline{\text { CrossRef }} \chi^{\top}$ 
[16] San, B. Ç., \&Tok, T. N. (2017). The relationship between teachers' work engagement and organizational commitment. Pamukkale University Journal of Social Sciences Institute, 26(1), 355-370.

\section{Google Scholar $\chi^{7}$}

[17] Van der Heijden, B. I., Van Vuuren, T. C., Kooij, D. T., \& amp; De Lange, A. H. (2015). Tailoring professional development for teachers in primary education. Journal of Managerial Psychology, 30(1), 22-37.

Google Scholar $\chi^{\top}$

\section{CrossRef $x^{7}$}

[18] Dixit, A., \&amp; Upadhyay, Y. (2021). Role of JD-R model in up ticking innovative work behaviour among higher education faculty. RAUSP Management Journal, 56(2), 156-169.

Google Scholar $X^{\lambda}$

[19] Crawford, E. R., LePine, J. A., \& Rich, B. L. (2010). Linking job demands and resources to employee engagement and burnout: A theoretical extension and meta-analytic test. Journal of Applied Psychology, 95(5), 834-848.
Google Scholar $X^{\top}$
CrossRef $x^{7}$

[20] BrynjulfHjertø, K., Merok Paulsen, J., \&amp; Petteri Tihveräinen, S. (2014). Social-cognitive outcomes of teachers' engagement in learning communities. Journal of Educational Administration, 52(6), 775-791.
Google Scholar ${ }^{\top}$
CrossRef $x^{\top}$

[21] Leontyeva, E. (2017). Innovative teaching methods for international students. New Trends and Issues Proceedings on Humanities and Social Sciences, 3(1), 157-165.

Google Scholar ${ }^{\top}$

[22] Nussbaum, M. C. (2006). Education and democratic citizenship: Capabilities and quality education. Journal of Human Development, 7(3), 385-395.
Google Scholar $X^{\top}$
CrossRef $x^{7}$

[23] Mammadova-GunayHasanova, I. (2019). Traditional and interactive teaching methods advantages and disadvantages: Comparative analysis. Azerbaijan Journal of Educational Studies, 229(229), 19-28.

Google Scholar $\chi^{7}$

[24] Thien, L. M., Adams, D., \& Koh, H. M. (2021). Nexus between distributed leadership, teacher academic optimism and teacher organisational commitment: A structural equation modelling analysis. International Journal of Educational Management, 35(4), 830-847.

Google Scholar $X^{\nearrow}$

[25] Chan, E. S., Ho, S. K., Ip, F. F., \& Wong, M. W. (2020). Self-efficacy, work engagement, and job satisfaction among teaching assistants in Hong Kong's inclusive education. SAGE Open, 10(3), 111.
Google Scholar $\not 7$
CrossRef $x^{\top}$

[26] Han, J., Yin, H., Wang, J., \& Zhang, J. (2019). Job demands and resources as antecedents of university teachers' exhaustion, engagement and job satisfaction. Educational Psychology, 40(3), 318-335.

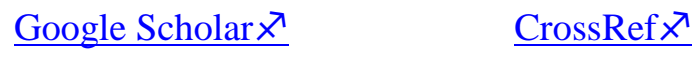

[27] Ahuja, S., \& Gupta, S. (2019). Organizational commitment and work engagement a s a facilitator for sustaining higher education professionals. International Journal of recent technology and engineering, 7(6), 1846-1849.

Google Scholar $\not$ '

[28] Bakker, A. B., Albrecht, S. L., \& Leiter, M. P. (2011). Key questions regarding work engagement. European Journal of Work and Organizational Psychology, 20(1), 4-28.

Google Scholar $\chi^{\top} \quad \underline{\text { CrossRef }} \chi^{\top}$ 
[29] Mäkinen, M. (2013). Becoming engaged in inclusive practices: Narrative reflections on teaching as descriptors of teachers' work engagement. Teaching and Teacher Education, 35(1), 51-61.

Google Scholar $\chi^{\nearrow}$

CrossRef $x^{\lambda}$

[30] Federici, R. A., \&Skaalvik, E. M.(2011). Principal self-efficacy and work engagement: Assessing a Norwegian principal self-efficacy scale. Social Psychology of Education, 14(4), 575-600.

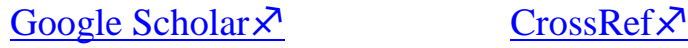

[31] Geldenhuys, M., Łaba, K., \& Venter, C. M. (2014). Meaningful work, work engagement and organisational commitment. SA Journal of Industrial Psychology, 40(1), 1-10.

Google Scholaræx

CrossRef $x^{\top}$

[32] Aithal, P. S. (2016). Student centric curriculum design and implementation - Challenges \& opportunities in business management \& IT education. IRA International Journal of Education and Multidisciplinary Studies, 4(3), 423-437.

Google Scholar $\chi^{\top} \quad$ CrossRef $\chi^{\top}$

[33] Yang, J., \& Tan, C. (2019). Advancing student-centric education in Korea: Issues and challenges. The Asia-Pacific Education Researcher, 28(6), 483-493.

$\underline{\text { Google Scholar } X^{\top} \quad \text { CrossRef } x^{\top}}$

[34] Riet, J. V., Ruiter, R. A., Werrij, M. Q., \& De Vries, H. (2008). The influence of self-efficacy on the effects of framed health messages. European Journal of Social Psychology, 38(5), 800-809. Google Scholar $\chi^{7}$

CrossRef $x^{\top}$

[35] Le Blanc, P. M., Schaufeli, W. B., Salanova, M., Llorens, S., \& Nap, R. E. (2010). Efficacy beliefs predict collaborative practice among intensive care unit nurses. Journal of Advanced Nursing, 66(3), 583-594.

Google Scholar ${ }^{7}$

$\underline{\operatorname{CrossRef}} x^{\top}$

[36] Salanova, M., Bakker, A. B., \&Llorens, S. (2006). Flow at work: Evidence for an upward spiral of personal and organizational resources*. Journal of Happiness Studies, 7(1), 1-22.

Google Scholar $x^{\top} \quad$ CrossRef $x^{\top}$

[37] Shah, M., \& Do, Q. T. (2017). The rise of quality assurance in Asian higher education. Chandos Publishing, 1-51. ISBN:9780081005590, 0081005598. Google Scholar $\chi^{7}$

[38] Žnidaršič, J., Vukovič, G., \& Marič, M. (2020). The relationship between work-life balance and job engagement: life satisfaction as a moderator. In Proceedings of FEB Zagreb International Odyssey Conference on Economics and Business (Vol. 2, No. 1, pp. 706-719). University of Zagreb, Faculty of Economics and Business. Google Scholar ${ }^{\top}$

[39] Bedarkar, M., \& Pandita, D. (2014). A study on the drivers of employee engagement impacting employee performance. Procedia - Social and Behavioural Sciences, 133(1), 106-115.

Google Scholar $X^{\nearrow} \quad$ CrossRef $X^{\top}$

[40] Yaniv, E., \& Farkas, F. (2005). The impact of person-organization fit on the corporate brand perception of employees and of customers. Journal of Change Management, 5(4), 447-461.

$\underline{\text { Google Scholar }{ }^{\top} \quad \underline{\text { CrossRef }}{ }^{\top}}$

[41] Greenhaus, J. H., Collins, K. M., \& Shaw, J. D. (2003). The relation between work-family balance and quality of life. Journal of Vocational Behavior, 63(3), 510-531.

Google Scholar ${ }^{\top} \quad$ CrossRef $\chi^{\top}$

[42] Tschannen-Moran, M., Hoy, A. W., \& Hoy, W. K. (1998). Teacher efficacy: Its meaning and measure. Review of Educational Research, 68(2), 202-248.

Google Scholar $X^{\top} \quad$ CrossRef $X^{\top}$

[43] Podsakoff, N., Whiting, S., Podsakoff, P., \& Blume, B. (2008). Individual- and organizationallevel consequences of organizational citizenship behaviors: A meta-analysis. PsycEXTRA Dataset. 94(1), 122-141. 


\section{Google Scholar $\chi^{\top} \quad$ CrossRef $x^{\nearrow}$}

[44] Hellriegel, D., Slocum, J. W., Jackson, S. E., Amos, T., Klopper, H., Louw, L., Louw, M., Oosthuizen, T., Perks, S., Staude, G., \& Zindiwe, S. (2012). Management 4th South African edition. OUP Southern Africa, 51-60.

CrossRef $X^{\lambda}$

[45] Eisenberger, R., Armeli, S., Rexwinkel, B., Lynch, P. D., \& Rhoades, L. (2001). Reciprocation of perceived organizational support. Journal of Applied Psychology, 86(1), 42-51.

Google Scholar $\chi^{\top} \quad \underline{\text { CrossRef } \chi^{\top}}$

[46] Maslach, C., \& Leiter, M. P. (2008). Early predictors of job burnout and engagement. Journal of Applied Psychology, 93(3), 498-512.

Google Scholar $X^{7} \quad$ CrossRef $\chi^{\top}$

[47] Smith, C. A., Organ, D. W., \& Near, J. P. (1983). Organizational citizenship behavior: Its nature and antecedents. Journal of Applied Psychology, 68(4), 653-663.

Google Scholar $\chi^{\top} \quad$ CrossRef $x^{\prime}$

[48] Sharma, U., \& Rajput, B. (2017). A study of employee engagement in information technology sector in India. ACADEMICIA: An International Multidisciplinary Research Journal, 7(5), 81-95.

Google Scholar $\chi^{\top}$

[49] Roberts, D. R., \& Davenport, T. O. (2002). Job engagement: Why it's important and how to improve it. Employment Relations Today, 29(3), 21-29.

Google Scholar $\not 7$

[50] Wilde, N., \& Hsu, A. (2019). The influence of general self-efficacy on the interpretation of vicarious experience information within online learning. International Journal of Educational Technology in Higher Education, 26(1), 1-20.

Google Scholar $x^{\top} \quad$ CrossRef $x^{\top}$

[51] Bandura, A. (1977). Self-efficacy: Toward a unifying theory of behavioural change. Psychological Review, 84(2), 191-215.

Google Scholar $\chi^{\top}$

CrossRef $x^{\top}$

[52] Gist, M. E., \& Mitchell, T. R. (1992). Self-efficacy: A theoretical analysis of its determinants and malleability. Academy of Management Review, 17(2), 183-211.

Google Scholar $\chi^{7} \quad \underline{\text { CrossRef }} \chi^{\nearrow}$

[53] Parker, P. D., \& Martin, A. J. (2009). Coping and buoyancy in the workplace: Understanding their effects on teachers' work-related well-being and engagement. Teaching and Teacher Education, 25(1), 68-75.

Google Scholar 7

CrossRef $x^{\top}$

[54] Schaufeli, W. B., \& Bakker, A. B. (2004). Job demands, job resources, and their relationship with burnout and engagement: A multi-sample study. Journal of Organizational Behavior, 25(3), 293315 .

Google Scholar $x^{7}$

$\underline{\operatorname{CrossRef}} x^{\top}$

[55] Schaufeli, W. B., Salanova, M., González-romá, V., \& Bakker, A. B. (2002). The Measurement of Engagement and Burnout: A Two Sample Confirmatory Factor. Analytic Approach. Journal of Happiness Studies, 3(1), 71-92.

\section{$\underline{\text { Google Scholar }{ }^{\top} \quad \underline{\text { CrossRef }}{ }^{7}}$}

[56] Eisenberger, R., Huntington, R., Hutchison, S., \& Sowa, D. (1986). Perceived organizational support. Journal of Applied Psychology, 71(3), 500-507.

Google Scholar $\chi^{\top} \quad \underline{\text { CrossRef }}{ }^{\top}$

[57] Rhoades, L., Eisenberger, R., \& Armeli, S. (2001). Affective commitment to the organization: The contribution of perceived organizational support. Journal of Applied Psychology, 86(5), 825-836.

Google Scholar $\chi^{\top}$

$\underline{\operatorname{CrossRef}} \chi^{\top}$ 
[58] VanBeek, I., Taris, T. W., \& Schaufeli, W. B. (2011). Workaholic and work engaged employees: Dead ringers or worlds apart? Journal of Occupational Health Psychology, 16(4), 468-482. Google Scholar ${ }^{\nearrow}$ CrossRef $x^{7}$

[59] Gorji, M. (2011). The effect of job burnout dimension on employees' performance. International Journal of Social Science and Humanity, 1(4), 243-246.

Google Scholar $\chi^{\top}$

[60] Bandura, A., \& Wood, R. (1989). Effect of perceived controllability and performance standards on self-regulation of complex decision making. Journal of Personality and Social Psychology, 56(5), 805-814.

Google Scholar $\not 7$

[61] Bakker, A. B. (2011). An evidence-based model of work engagement. Current Directions in Psychological Science, 20(4), 265-269.
Google ScholarX
CrossRef $X^{7}$

[62] Shailashree, V. (2016). Student engagement: A case study of Srinivas institute of management studies. International journal of Current Research and Modern Education, 1(1), 362-368.
Google Scholar $\not 7$
CrossRef $x^{7}$

[63] Aithal, P. S., \& Suresh Kumar, P. M. (2016). Maintaining Teacher Quality in Higher Education Institutions. International Journal of Current Research and Modern Education, 1(1), 701-711. Google Scholar $\chi^{\top}$

CrossRef $x^{\top}$

[64] Wagner, D. A. (2010). Quality of education, comparability, and assessment choice in developing countries. Compare: A Journal of Comparative and International Education, 40(6), 741-760. Google Scholar $\chi^{\nearrow}$

CrossRef $x^{7}$

[65] Deme, M., \& Mahmoud, A. M. (2020). Effect of quantity and quality of education on per capita real-GDP growth: Evidence from low- and middle-income African countries. Applied Economics, 52(57), 6248-6264. Google Scholar ${ }^{7}$

CrossRef $x$

[66] Miller, G., \& Elman, E. (2013). Improving the quality of education: Kenya's next challenge. Geography, 98(1), 24-32. Google Scholar $\chi^{\top}$

CrossRef $X$

[67] Sagnak, M., Ada, N., Kazancoglu, Y., \& Tayaksi, C. (2017). Quality function deployment application for improving quality of education in business schools. Journal of Education for Business, 92(5), 230-237.

Google Scholar ${ }^{7}$

CrossRef $x^{\top}$

[68] Haddad, M. A., Freguglia, R., \& Gomes, C. (2016). Public spending and quality of education in Brazil. The Journal of Development Studies, 53(10), 1679-1696.
Google Scholar ${ }^{\top}$
CrossRef $x^{7}$

[69] Ji, Z. (2009). Teaching evaluation. Chinese Education \& Society, 42(2), 7-19. Google Scholar $\chi^{7}$

CrossRef $x^{\top}$

[70] Kariyana, I., \& Sonn, R. A. (2014). School-oriented issues affecting the quality of education: A qualitative study for academic improvement. Journal of Social Sciences, 41(3), 313-323. Google Scholar $x^{7}$

CrossRef $x^{7}$

[71] Hasrati, M. (2021). Putting the employment status of faculty into the quality of education: A Canadian case study. Innovations in Education and Teaching International, 1(1), 1-11. Google Scholar $\chi^{7}$

[72] Santos, M. E. (2011). Human capital and the quality of education in a poverty trap model. Oxford Development Studies, 39(1), 25-47. Google Scholar $\chi^{\top}$ CrossRef $x^{\top}$ 
[73] Stepanova, T. (2004). Modernization of the rural school: The accessibility and quality of education. Russian Education \& Society, 46(12), 18-29.

Google Scholar ${ }^{\nearrow} \quad$ CrossRef $\chi^{\top}$

[74] Musambachime, M. (1990). The impact of rapid population growth and economic decline on the quality of education: The case of Zambia. Review of African Political Economy, 17(48), 81-92.

Google Scholar $X^{\top}$

CrossRef $X^{\top}$

[75] Gurova, G., Piattoeva, N., \& Takala, T. (2015). Quality of education and its evaluation: An analysis of the Russian academic discussion. European Education, 47(4), 346-364.

Google Scholar $\chi^{\top} \quad$ CrossRef $\chi^{\top}$

[76] Zholkov, S. I. (2010). The quality of education is the quality of society. Russian Education \& Society, 52(5), 42-54.

Google Scholar $X^{7}$

\section{CrossRef $x^{\top}$}

[77] Crosling, G., Nair, M., \& Vaithilingam, S. (2014). A creative learning ecosystem, quality of education and innovative capacity: A perspective from higher education. Studies in Higher Education, 40(7), 1147-1163.

\section{Google Scholar $\chi^{\top} \quad \underline{\text { CrossRef }} \chi^{\top}$}

[78] Kong, S. C. (2009). An empirical study of school-based planning for the use of information technology to improve the quality of education in the twenty-first century. Technology, Pedagogy and Education, 18(3), 343-359.

Google Scholar 7 CrossRef 7

[79] Karademir, T. (2015). Investigation of organizational confidence level of school managers' and teachers' in terms of quality of education. The Anthropologist, 19(2), 397-405.

Google Scholar $x^{\top} \quad$ CrossRef $x^{\top}$

[80] Loerbroks, A., Glaser, J., Vu-Eickmann, P., \& Angerer, P. (2017). Physician burnout, work engagement and the quality of patient care. Occupational Medicine, 67(5), 356-362.

Google Scholar $\chi^{\lambda} \quad$ CrossRef $\chi^{\lambda}$

[81] Koch, A. R., Binnewies, C., \& Dormann, C. (2014). Motivating innovation in schools: School principals' work engagement as a motivator for schools' innovation. European Journal of Work and Organizational Psychology, 24(4), 505-517.

Google Scholar 7 CrossRef $x^{7}$

[82] Simbula, S., Guglielmi, D., \& Schaufeli, W. B. (2011). A three-wave study of job resources, selfefficacy, and work engagement among Italian schoolteachers. European Journal of Work and Organizational Psychology, 20(3), 285-304.

Google Scholar $X^{\top}$

CrossRef $x$

[83] Cheng, J., Chang, S., Kuo, J., \& Cheung, Y. (2014). Ethical leadership, work engagement, and voice behavior. Industrial Management \& Data Systems, 114(5), 817-831.

Google Scholar $x^{\top} \quad$ CrossRef $x^{\top}$

[84] Guglielmi, D., Bruni, I., Simbula, S., Fraccaroli, F., \& Depolo, M. (2015). What drives teacher engagement: A study of different age cohorts. European Journal of Psychology of Education, 31(3), 323-340.

Google Scholar $\chi^{\top}$

$\underline{\text { CrossRef } x}$

[85] Rich, B. L., Lepine, J. A., \& Crawford, E. R. (2010). Job engagement: Antecedents and effects on job performance. Academy of Management Journal, 53(3), 617-635.

$\underline{\text { Google Scholar }{ }^{\nearrow} \quad \underline{\text { CrossRef }} \not}$

[86] Hosseini, S., \& Haghighi Shirazi, Z. R. (2021). Towards teacher innovative work behavior: A conceptual model. Cogent Education, 8(1), 1869364.

Google Scholar ${ }^{\top} \quad \underline{\text { CrossRef }} \not$

[87] Ryu, G., \& Shim, D. (2020). Developmental leadership, skill development, and work engagement. International Review of Public Administration, 25(1), 64-79. 


\section{Google Scholar $\chi^{\top} \quad$ CrossRef $\chi^{\nearrow}$}

[88] Petchsawang, P., \& McLean, G. N. (2017). Workplace spirituality, mindfulness meditation, and work engagement. Journal of Management, Spirituality \& Religion, 14(3), 216-244.

Google Scholar $\chi^{\top} \quad$ CrossRef $\chi^{\top}$

[89] Miner, M., Bickerton, G., Dowson, M., \& Sterland, S. (2015). Spirituality and work engagement among church leaders. Mental Health, Religion \& Culture, 18(1), 57-71.

Google Scholar $x^{\top} \quad$ CrossRef $x^{\top}$

[90] Den Hartog, D. N., \& Belschak, F. D. (2012). Work engagement and machiavellianism in the ethical leadership process. Journal of Business Ethics, 107(1), 35-47.

Google Scholar ${ }^{\top} \quad$ CrossRef $\chi^{\top}$

[91] Yucel, I., Şirin, M. S., \& Baş, M. (2021). The mediating effect of work engagement on the relationship between work-family conflict and turnover intention and moderated mediating role of supervisor support during global pandemic. International Journal of Productivity and Performance Management, ahead-of-print(ahead-of-print). https://doi.org/10.1108/IJPPM-072020-0361.

Google Scholar $\chi^{7}$

[92] Sekhar, C. (2021). Do high-commitment work systems engage employees? Mediating role of psychological capital. International Journal of Organizational Analysis, ahead-of-print(aheadof-print). https://doi.org/10.1108/IJOA-10-2020-2466.

Google Scholar $\chi^{\nearrow}$

[93] Aithal, P. S., \& Aithal, S. (2019). Autonomy for universities excellence - Challenges and opportunities. International Journal of Applied Engineering and Management Letters, 3(2), 36 50. ISSN 2581-7000 (2019). http://doi.org/10.5281/zenodo.3464710.

Google Scholar ${ }^{\top}$

[94] Aithal, P. S., \& Aithal, S. (2020). Implementation strategies of higher education part of national education policy 2020 of India towards achieving its objectives. International Journal of Management, Technology, and Social Sciences, 5(2), 283-325.
Google Scholar $\chi^{\top}$
CrossRef $x^{7}$

[95] Aithal, P. S., \& Suresh Kumar, P. M. (2016). Opportunities and Challenges for Private Universities in India. International Journal of Management, IT and Engineering, 6(1), 88-113.

Google Scholar $\chi^{\nearrow} \quad \underline{\text { CrossRef }} \not$

[96] Bhatta B., S. R., \& S.G., V. K. (2017). A study of student perception on printed study material distribution model at Srinivas Institute of management studies. International Journal of Management, Technology, and Social Sciences, 2(1), 66-74.
Google Scholar $\not$ '
CrossRef $x^{2}$

[97] Varambally, K. V. M., Sujaya, H., \& Aithal, P. S. (2020). Innovation in Teaching-Learning Process: An Experiment of Srinivas University. International Journal of Case Studies in Business, IT, and Education (IJCSBE), 4(1), 1-7.

Google Scholar X

[98] Shailashri, V. T., \& Shenoy, S. (2016). Innovation a key towards employee engagement. International Journal of Management, Technology, and Social Sciences, 1(1), 4347.

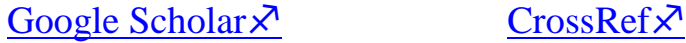

[99] Aithal, P. S., \& Aithal, Shubhrajyotsna, (2019). A new attitude-behaviour (AB) theory for organizational leadership. International Journal of Management, Technology, and Social Sciences, 4(1), 83-97.

Google Scholar $x^{7}$

CrossRef $x^{\top}$

[100] Shailashri, V. T. \& Shenoy, S. (2017). Indian education - Global relevance. International Journal of Case Studies in Business, IT, and Education, 1(2), 93-102. 
Google Scholar $\chi^{\top}$

CrossRef $x^{\lambda}$

[101] Aithal, P. S., Srinivas Rao, A., \& Suresh Kumar, P. M. (2015). Quality Enhancement in Higher Education. International Journal of Multidisciplinary Research and Development Institutions, 2(5), 18-31.

Google Scholar ${ }^{7}$

$\underline{\operatorname{Cross} \operatorname{Ref} X^{\top}}$ 